UDC 629.735.33.02-027.3:621.793.71

doi: $10.32620 /$ aktt.2021.1.05

KUN TAN ${ }^{1,2}$, S. MARKOVYCH ${ }^{1}$, WENJIE HU ${ }^{1,4}$, O. SHORINOV $^{1}$, YURONG WANG ${ }^{3}$

${ }^{1}$ National aerospace university «Kharkiv Aviation Institute», Ukraine

${ }^{2}$ China Scholarship Council

${ }^{3}$ Commercial Aircraft Corporation of China Ltd

${ }^{4}$ School of Aeronautics and Astronautics, Nanchang Institute of Technology, China

\title{
REVIEW OF APPLICATION AND RESEARCH BASED ON COLD SPRAY COATING MATERIALS
}

\begin{abstract}
Cold spray technology is an advanced spray technology, and its technical principle is the same as that of additive manufacturing technology. Cold spraying technology combines multiple advantages in the spraying field: not only can the deposition of thick coatings be achieved, but the coatings prepared by this technology have the characteristics of high density, low oxygen content, good mechanical properties of the coating surface, and high deposition efficiency. Cold spraying technology can prepare corrosion-resistant coatings, high-temperature resistant coatings, wear-resistant coatings, conductive coatings, anti-oxidation coatings, and other functional coatings. After decades of development and exploration, cold spraying technology is preparing metal coatings. The application is very wide and the process is mature; the same cold spray technology can also prepare nonmetallic coatings. Mainly to immerse repair and protect the surface of metal alloy parts and a small part of nonmetal parts, so that these parts have better mechanical properties and mechanical behavior. This article mainly reviews the application of cold spray technology in the field of spray materials and summarizes the existing conventional metal series, rare metal series and non-metal material, conventional non-ferrous metals: copper, titanium, aluminum and nickel. Metal materials are currently widely used in the field of cold spraying. Among them, titanium-based metals restrict their applications due to their own properties; rare metals: tungsten, tantalum, and niobium-based metal materials. The application of rare metals in cold spraying is still in its infancy stage; non-metallic materials: polymer materials and ceramic powder materials, non-metallic materials have the characteristics of surface modification and strengthening technology, but also have low oxygen content, low thermal stress, high density, good bonding strength, in the deposition process and the substrate will not change the advantages of physical organization structure. Finally, the existing problems of rare metal materials and non-metal materials are raised.
\end{abstract}

Keywords: cold spraying; aviation; metal materials; polymer materials; ceramic powder materials.

\section{The principle of cold spray technology}

The cold spray technology was invented in the 1980s by researchers at the Institute of Theoretical and Applied Mechanics, Siberian Branch of Russia. This technology uses ultra-high-speed powder particles to hit the surface of the substrate, and finally the powder particles are deposited on the surface of the substrate. Coating method [1]. Through decades of research and academic exchanges, many countries around the world have also established cold spray technology research and development teams to conduct in-depth research and exploration on the spray deposition principle and application field expansion of cold spray systems.

Cold Gas Dynamic Spray (Cold Gas Dynamic Spray, referred to as CS), referred to as cold spray technology. This technology is a new type of spray deposition technology developed on the basis of aerodynamic science. Spray deposition is a process in which powder particles are accelerated in the Laval nozzle by the action of an acceleration medium (usually nitrogen, air or helium). The final ultra-high speed $(300 \mathrm{~m} / \mathrm{s}-1200 \mathrm{~m} / \mathrm{s})$ powder particles hit the substrate to achieve deposition, and eventually form a uniform and dense coating on the substrate [2-3]. Only when the powder particle material exceeds the critical speed specific to the sprayed material, the powder particles are adhered to the surface of the substrate through plastic deformation, and finally the deposition on the substrate can be achieved. The main reason is "adiabatic shear instability" [4].

There are many factors that affect the physical properties, mechanical properties and Microstructure of the coating, such as: the geometry of the Laval nozzle, the characteristics of the powder particle material, the 
temperature of the spray material and the substrate, the spray distance, the speed of the powder particles and the spray angle and other factors.

\section{Applications of cold spray technology}

Cold spray technology prepares other functional coatings such as corrosion-resistant coatings, hightemperature-resistant coatings, wear-resistant coatings, conductive coatings, and oxidation-resistant coatings by depositing coatings, which can repair parts that have the above problems in order to improve the physical and mechanical properties of parts and extend service life, it has very good economy, such as: turbine blades, pistons, bearings, cylinders, valves, seals and casings and other parts. Now cold spraying technology has broad application prospects in the fields of aviation, aerospace, ships, automobiles, chemicals, electronics, paper making and machinery.

The materials of the cold spraying technology are initially developed around conventional metal materials. Through continuous research and development, they have been extended to other materials. They have been successfully used in the cold spraying technology and have achieved good results. The materials currently available for cold spray technology can be classified into six categories: metals, metal matrix composites, ceramics, polymers, nanostructured materials and non-metallic base materials. For example: repairing space shuttle solid fuel rocket thrusters with $\mathrm{Al}$ coating, repairing components in aircraft structures, repairing gas turbine sealed enclosures [5, 6]; cold spray technology MCrAlY and TBCS materials have very good high temperature resistance, so they are often used as a material for preparing high temperature resistant coatings and thermal barrier coatings; cold spray technology $\mathrm{Cu}-\mathrm{Cr}-\mathrm{Al}$ material has very good oxidation resistance, so it is often used to prepare anti-oxidation layers; In cold spray technology, cermet, metal-based Composite materials and wear-resistant alloys have very good wear resistance, so they are often used to prepare wear-resistant coatings; $\mathrm{Mg}, \mathrm{Al}, \mathrm{Cu}$, Ti, of which $\mathrm{Mg}$ and $\mathrm{Al}$ are light metals and are often used in aircraft, missiles, torpedoes, radar, satellites, with high specific strength characteristics alloys are mainly used in aircraft and engine structural parts [7]. Table 1 shows the spraying materials commonly used in current cold spraying technology.

\section{Application of spray materials}

\subsection{Cu-based metal materials}

In the field of non-ferrous metals, $\mathrm{Cu}$ is second only to $\mathrm{Al}$. $\mathrm{Cu}$ is susceptible to oxidation at high temperatures, and pores are easily generated during the precipitation of supersaturated hydrogen [8]. Cold spray technology is a low-temperature spray technology, so $\mathrm{Cu}$ can effectively avoid the occurrence of oxidation problems of $\mathrm{Cu}$ powder particles during spraying.

Table 1

The materials that can be used for cold spraying

\begin{tabular}{|c|c|}
\hline Materials & Specific materials \\
\hline Metal & $\begin{array}{c}\mathrm{Al}, \mathrm{Zn}, \mathrm{Cu}, \mathrm{Ni}, \mathrm{Ca}, \mathrm{Ti}, \mathrm{Ag}, \\
\mathrm{Co}, \mathrm{Fe}, \mathrm{Nb}, \mathrm{W}\end{array}$ \\
\hline $\begin{array}{l}\text { High melting } \\
\text { point metal }\end{array}$ & Mo, Ta \\
\hline Alloy & $\begin{array}{c}\text { Ni-Al, Al-Fe, Al-Cu, Cu-W, Al } \\
\text { 7075, Al A357, Ti-6Al-4V }\end{array}$ \\
\hline Ceramic & $\begin{array}{c}\mathrm{Al} 2 \mathrm{O} 3, \mathrm{Cr} 2 \mathrm{O} 3, \mathrm{SiC}, \mathrm{WC}, \mathrm{TiO} 2, \\
\text { Cr3C2-NiCr, WC-Co, TiN, }\end{array}$ \\
\hline Polymer & UHMWPE, HDPE, PA-12, PFA \\
\hline
\end{tabular}

Zhang [9] and other scholars prepared a $\mathrm{Cu}-\mathrm{Ti}-\mathrm{B} 4 \mathrm{C}$ composite coating (powder composition $\mathrm{Cu}=81.99 \%$, $\mathrm{Cu}=14.64 \%, \mathrm{~B} 4 \mathrm{C}=3.37 \%$ ) on a $\mathrm{Cu}$ substrate using cold spray technology, and the internal structure of the coating is dense, The porosity is about $1 \%$, and the interface with the substrate is very good, and no obvious oxidation occurs during the spraying process. Zhang [10] and other researchers prepared a $\mathrm{Cu}-\mathrm{MoS} 2$ composite wear-reducing coating on the surface of Al6060 alloy using cold spray technology. The $\mathrm{Cu}-\mathrm{MoS} 2$ composite wear-reducing coating reduced the friction coefficient by $75 \%$ compared with the pure $\mathrm{Cu}$ coating. $\mathrm{Xu}$ [11] and other researchers used cold spray technology to prepare conductive $\mathrm{Cu}$ coatings on the surface of Al6061 alloy using $\mathrm{Cu}$ as the spray material. In the cold spray technology, $\mathrm{Cu}$ was used as the deposition material to study the mechanical properties of the coating. Li [12] and other researchers developed a rapidly cooling $\mathrm{Cu}-$ $4 \mathrm{Cr}-2 \mathrm{Nb}$ alloy layer on the rocket thrust device components using cold spray technology. Vacuum heat treatment of the coating at an annealing temperature of $350{ }^{\circ} \mathrm{C}$, the Microhardness reaches the maximum, the coating performance can reach the performance of the coating prepared by VPS technology. Using cold spray technology to prepare the $\mathrm{Cu}$ coating and heat-treating the coating, research shows that the average tensile strength of the $\mathrm{Cu}$ coating after heat treatment and annealing increases by $34.27 \%$ [13]. The hardness of the $\mathrm{Cu}$ alloy coating prepared by the cold spray technique is obviously higher than that of the pure $\mathrm{Cu}$ coating [14]. Huang [15]. used cold spray technology to prepare $\mathrm{Cu}$ coatings on the surface of $\mathrm{Al}$ alloys, and obtained the relationship between the bonding strength of $\mathrm{Cu}$ coatings and substrates and particle velocity, as shown in Figure 1. 


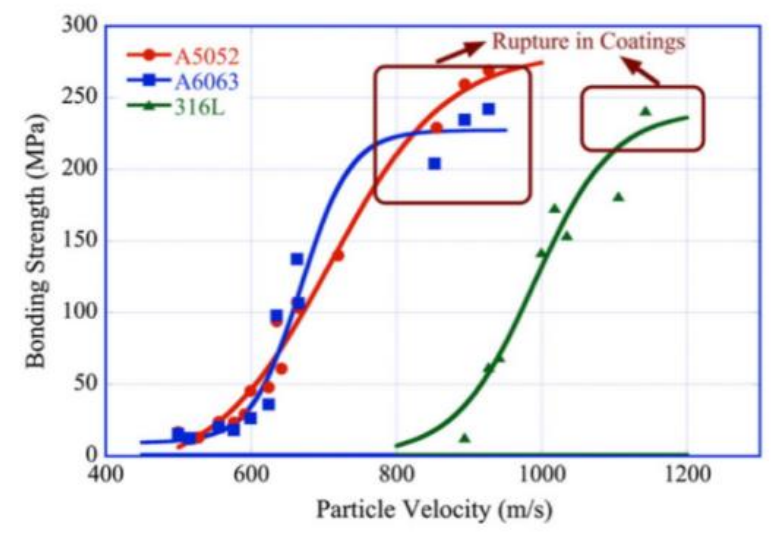

Figure 1. The relationship between the bonding strength and the speed of $\mathrm{Cu}$ powder particles [15]

\subsection{Ti series metal materials}

Ti alloys have been developed since the last fifty years of the last century. Ti alloys have such outstanding advantages as high strength, corrosion resistance, and high temperature resistance. Therefore, Ti alloys are widely used as materials for core components of aircraft. Many researchers have prepared pure Ti coatings and Ti$6 \mathrm{Al}-4 \mathrm{~V}$ coatings by cold spray technology, and studied their Microstructure and mechanical properties. Figure 2 shows the Microstructure of pure $\mathrm{Ti}$ and $\mathrm{Ti}-6 \mathrm{Al}-4 \mathrm{~V}$ coatings prepared by cold spray technology [16] researchers such as Li [17] used cold spray technology to prepare porous Ti materials. Because Ti and its alloys have high hardness, they are not likely to deform during the cold spray process.
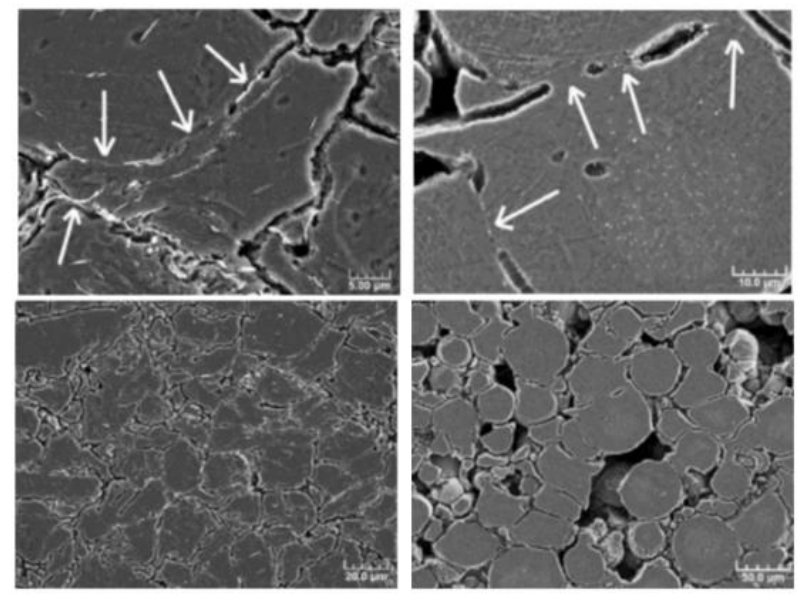

Figure 2. Microstructure of the cross section of pure Ti and Ti-6Al-4V coating [16]

Wang [18] and other researchers used cold spray technology to prepare a $\mathrm{Ti}$ metal coating on a $1 \mathrm{Cr} 13$ stainless steel substrate, and XRD analysis confirmed that there was basically no oxide phase formed in the $\mathrm{Ti}$ coating. Luo [19] and other researchers used in-situ Shot Peening (SP) to prepare high-density CP Ti and Ti-6Al$4 \mathrm{~V}$ coatings using cold spray technology. The research results show that the proportion of SP powder particles increases from 0 to 70 vol. \%, the porosity of $\mathrm{CP} \mathrm{Ti}$ and Ti-6Al-4V coatings is reduced, and the work hardening effect is significantly enhanced, as shown in Figure 3.

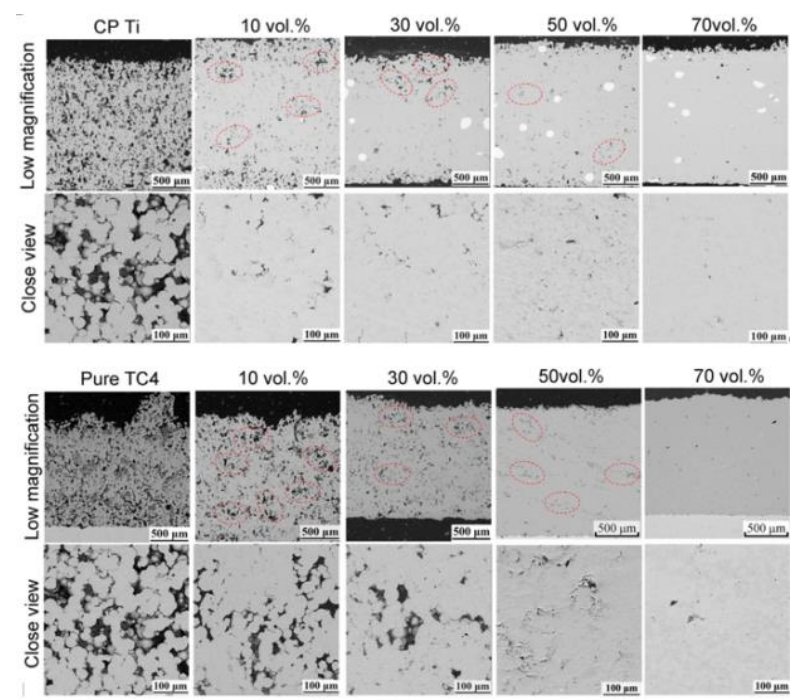

Figure 3. The change of the cross-sectional microstructure of pure Ti and Ti-6Al-4V with increasing proportion [19]

\subsection{Al-based and Ni-based metal materials}

Aluminum and $\mathrm{Al}$ alloys are widely used in aerospace, marine and automotive fields. Al has the characteristics of low density, high tensile strength, corrosion resistance and easy forming. $\mathrm{Al}$ is widely used as a spraying material in cold spraying technology. At present, many researchers are devoted to studying pure $\mathrm{Al}$ and $\mathrm{Al}$ alloy coatings. Compared with copper, $\mathrm{Al}$ powder is easier to deposit on the substrate, but its density is lower than that of $\mathrm{Cu}$ coating, because the density of $\mathrm{Al}$ is lower than that of $\mathrm{Cu}$. Zhang [20] and other researchers used $\mathrm{Al}$ powder with a purity of $99.9 \%$ as a spraying material, prepared $\mathrm{Al}$ coatings on 45 steel by cold spraying technology, and further studied the effect of spraying distance on the Al coating. The results show that when the spraying distance is $30 \mathrm{~mm}$, the deposition efficiency and microhardness of the $\mathrm{Al}$ coating are higher, and the combination effect with the substrate is better. CHAMPAGNE [21] and other researchers used cold spray technology to repair the $\mathrm{Mg}$ alloy crankcase shell by deposit coating with CP-Al powder as the material. The results showed that the bonding strength was $8.6 \mathrm{Mpa}$ and $71.3 \mathrm{Mpa}$ respectively, 
and the salt spray test was $336 \mathrm{~h}$ and $610 \mathrm{~h}$ respectively no corrosion and other phenomena occur, indicating that the Al coating has good corrosion resistance. Novoselova $\mathrm{T}$. [22] and other researchers used cold spray technology to prepare the Ti-Al coating. After the heat treatment process was applied to the coating, the inter metallic compounds TiAl3, $\alpha$-TiAl2, Ti-Al and Ti3 Al were generated, compared to the traditional Ti-Al coating preparation Method, cold spraying is more cost-effective.

Regarding the application of $\mathrm{Ni}$ as a spray material in cold spray technology, Elisa [23] and other researchers used Inconel 718-Ni (1: 1) as a spray material, and used high-pressure cold spray technology with Nitrogen as an accelerating medium on stainless steel substrates. In the coating, only $30 \mathrm{wt} \%$ of Inconel 718 was retained in the coating. The effect of the corrosion rate was studied by operating variables. The results show that The corrosion feed rate is $2 \mathrm{~g} / \mathrm{min}$, the corrosion product size is 60 microns, the collision angle is $90^{\circ}$, and the corrosion rate is the smallest. researchers such as Marios [24] also used pure $\mathrm{Ni}$ and Inconel 718 powder as a spraying material, and used high-pressure cold spraying technology to prepare high-quality coatings on stainless steel substrates using Nitrogen as an acceleration medium. Studies have shown that by using pure $\mathrm{Ni}$ powder the addition of Inconel 718 powder particles can enhance the cavitation resistance of the $\mathrm{Ni}$ coating, and the hardness of the coating surface can be increased. The composite coating has a higher porosity, but compared with pure $\mathrm{Ni}$ coating, it can show excellent Anticavitation. Makarov [25] and other researchers used NiTi composite powder and combined with nano-material $\mathrm{WC}$ as a spraying material. The results show that the use of cold spray technology to prepare Ni-TiWC coating can significantly improve the microhardness of the substrate surface, from $600 \mathrm{HV} 50$ Increased to $1300 \mathrm{HV} 50$. Mieczyslaw [26] and other researchers used cold spray technology to prepare Ni coatings on Al7050 alloy. The study found that the size of $\mathrm{Ni}$ powder material has a significant effect on the corrosion resistance of $\mathrm{Ni}$ coatings, and the porosity of $\mathrm{Ni}$ coatings will increase with the size of Ni powder increases with the increase of size. With the reduction of $\mathrm{Ni}$ powder diameter, the corrosion rate of $\mathrm{Ni}$ coating in chloride environment will decrease. The surface can be obtained by using irregular spherical or dendritic structure Ni powder as the spray material. Smooth and highly corrosion-resistant $\mathrm{Ni}$ coating. Wei [27] and other researchers used cold spray technology to prepare a fully dense Ni coating with a thickness of about 150 microns on the surface of AZ31B $\mathrm{Mg}$ alloy. After 1000 hours of immersion test and 1000 hours of $\mathrm{NaCl}$ salt spray test, the cold spray technology was further verified the prepared Ni coating has very good corrosion resistance.

\subsection{Tungsten series, Tantalum series and Niobium series metal materials}

Tungsten is an extremely refractory metal with a melting point of up to $3400^{\circ} \mathrm{C}$ and a density of $19.3 \mathrm{~g} / \mathrm{cm}^{3}$, and it has the characteristics of high hardness, low expansion coefficient, low saturation vapor pressure and good conductivity [7]. If cold spraying technology is used to prepare tungsten coating on the surface of aircraft engine turbine blades as a high temperature resistant coating, it will be a very important breakthrough. Aaron [28] and other researchers used $\mathrm{Cu}$ plated tungsten powder as a spraying material to prepare a composite high-temperature resistant coating by cold spraying technology. The concentrations of tungsten-Cu were $80 \mathrm{~W}-20 \mathrm{Cu}$ wt $\%, 85 \mathrm{~W}-15 \mathrm{Cu}$ wt $\%$ and $90 \mathrm{~W}-10 \mathrm{Cu}$ wt $\%$, The research results show that the content of tungsten in the composite coating after spraying is far less than the amount of the original spray powder. The Microstructure evidence shows that the $\mathrm{Cu}$ coating and tungsten particles are separated during the spraying process, as shown in Figure 4.

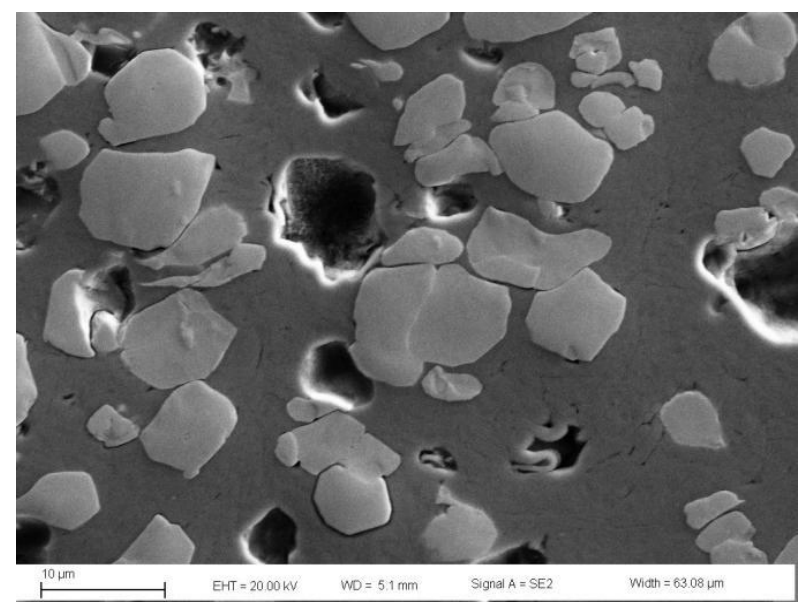

Figure 4. Magnified $80 \mathrm{~W}-20 \mathrm{Cu}$ wt $\%$ coating sample by microscope [28]

Resulting in a decrease in the content of tungsten on the coating, indicating that tungsten is a metal material that is extremely difficult to prepare the coating by cold spray technology. Kang [29] and other researchers used tungsten / Cu mixed powder as the spraying material, and used cold spraying technology to deposit the tungsten / $\mathrm{Cu}$ composite coating on the low carbon steel substrate. The research results show that the porosity will change with the presence of tungsten. No oxidation was found in the $\mathrm{Cu}$ in the composite coating. researchers such as Jones [30] used Supersonic Laser Deposition (SLD) to prepare a fully dense tungsten coating on a Mo substrate, as shown in Figure 5. 


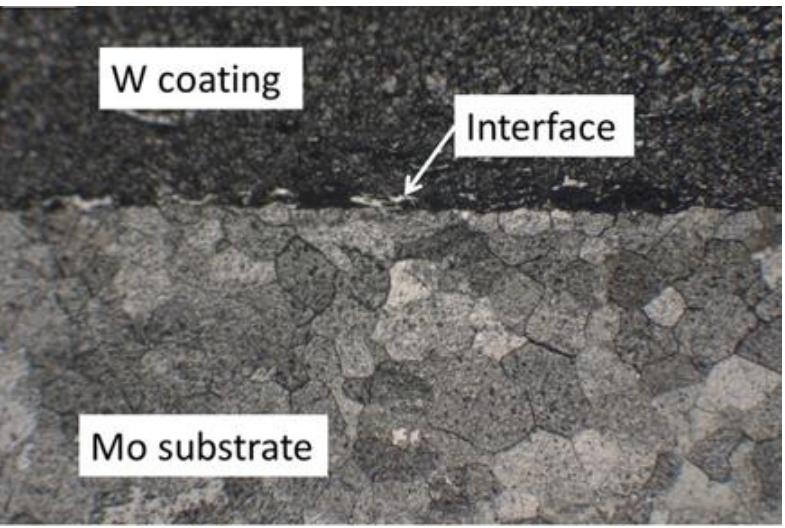

Figure 5. Tungsten coating and molybdenum substrate under optical micrograph [30]

The results show that the tensile strength of the tungsten coating is $724 \mathrm{Mpa}$, and the tensile strength of forged tungsten is comparable; it is worth noting that the working principle of Supersonic Laser Deposition (SLD) technology is similar to cold spray technology.

Tantalum metal has a melting point of up to $3033^{\circ} \mathrm{C}$ and a density of $16.68 \mathrm{~g} / \mathrm{cm}^{3}$. It is better than tungsten and molybdenum at room temperature in process ability, weld ability, ductility and oxidation resistance. It is an important material for high-temperature structures required in the aerospace industry. Tantalum and its alloys have poor oxidation resistance, and oxidation begins at $600{ }^{\circ} \mathrm{C}[31,32]$. The plasticity of tantalum is very suitable for use as a spray material for cold spray technology. Koivuluoto [33] and other scholars used cold spray technology to prepare tantalum coatings, and found that the purity and density of tantalum coatings are very high under scanning electron microscope, Under two different temperature conditions of normal temperature and $80^{\circ} \mathrm{C}$, the corrosion test was carried out in $3.5 \mathrm{wt} \%$ $\mathrm{NaCl}$ and 40 wt $\% \mathrm{H}_{2} \mathrm{SO}_{4}$ solution. The tantalum coating performed well in all corrosion tests, which further indicated that the tantalum coating was dense. researchers such as Koivuluoto [34] also used cold spray technology to prepare tantalum coatings on steel surfaces. The results of electrochemical tests in $1 \mathrm{M} \mathrm{KOH}$ solution showed that the tantalum coatings prepared by cold spraying technology were better than those prepared by plasma spraying. The layer has more stable passivation performance. In $1 \mathrm{wt} \% \mathrm{HF}$ solution, the performance of tantalum coating prepared by cold spraying technology is better than bulk tantalum. Bolelli [35] and other researchers prepared a tantalum coating on the surface of steel and Al using cold spray technology, and further studied the stress and strain behavior of the coating using the depth-sensing spherical and sharp (Berkovich) indentation testing method. The size of the tantalum material does not affect the mechanical properties of the coating. The layered structure has a direct relationship with the mechanical properties of the coating, and the density of the tantalum coating is good. Kumar [36] and other researchers prepared the tantalum coating by cold spray technology, The tantalum coating is heat treated at different temperatures to further optimize the mechanical properties of the coating, The study found that the tantalum coating was found when the heat treatment temperature was $1500{ }^{\circ} \mathrm{C}$ the mechanical properties of the layer are comparable to those of tantalum blocks. At the same time, the author also conducted a test evaluation and electrochemical test of the corrosion performance of the tantalum coating in $1 \mathrm{M} \mathrm{KOH}$ solution. The study found that the tantalum coating is very dense.

Niobium has a melting point of $2467{ }^{\circ} \mathrm{C}$ and a density of $8.57 \mathrm{~g} / \mathrm{cm}^{3}$. It has good ductility, stable physical and chemical properties and high-temperature mechanical properties. It is very stable in corrosive media and is widely used in the aerospace field. It can be used to make liquids and orbit control rocket engine nozzle [7]. Although the limit working temperature of niobium alloy is higher than that of Ni-based and cobalt-based superalloys, the oxidation resistance of niobium alloy is poor. When the temperature exceeds $600^{\circ} \mathrm{C}$, pure niobium will appear powdering failure, which seriously restricts the preparation of niobium-based materials and development [37].

Niobium powder is used as a spraying material, and cold spraying technology is used to prepare a niobium coating with air as an acceleration medium. After that, heat treatment is used to eliminate the gap of the niobium coating and the interface between the deformed particles, thereby improving the mechanical properties of the coating. The porosity of the coating is reduced to $0.1 \%$. When the heat treatment temperature reaches $1500{ }^{\circ} \mathrm{C}$, the elastic model of the niobium coating reaches $103 \mathrm{Gpa}$, while the elastic modulus of the niobium block is $105 \mathrm{Gpa}$, and the strength of the grain boundary of the niobium coating is increased by $750 \%$; The corrosion rate of the coating is $0.443 \mathrm{MPY}$ and 0.498 MPY of the niobium block material. It can greatly improve the corrosion performance of the coating under the annealing process. The research results also found that when the recrystallization temperature of niobium is close to $1250{ }^{\circ} \mathrm{C}$ or annealed at a higher temperature, the niobium coating can almost achieve the performance of niobium block [38]. Kumar [39] and other researchers can obtain a good combination of deposited coatings when the spray speed of niobium particles is $515 \mathrm{~m} / \mathrm{s}$ through numerical simulation of multiple particles.

\subsection{Polymer materials}

The techniques commonly used to prepare polymer coatings are: plasma spraying, arc spraying, flame spraying and cold spraying [40-43]. As a spray materials 
of cold spray technology, polymer materials have remarkable characteristics, good elastoplasticity, light weight, insulation and heat insulation. The materials usually used to prepare polymer coatings are mainly near spherical, as shown in Figure 6 [43].

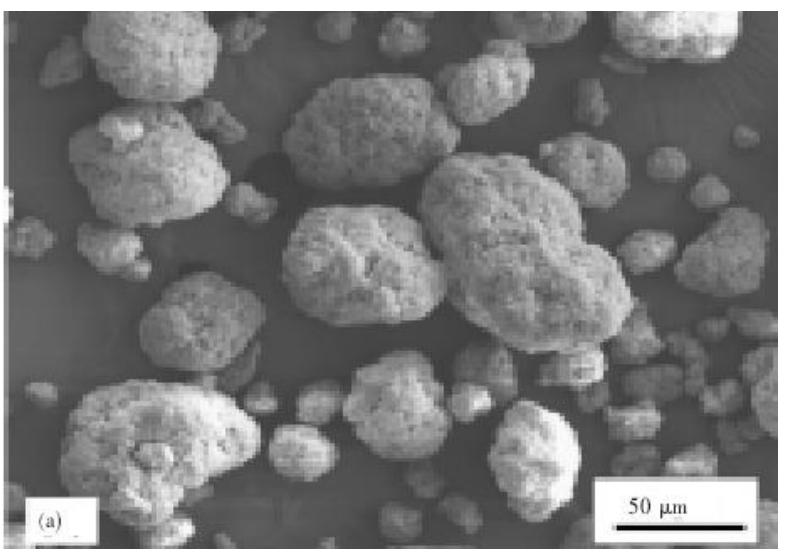

Figure 6. LIMA C near-spherical UHMWPE particles [43]

Cold spraying technology is a low-temperature spraying technology, so that the polymer material can maintain its own characteristics and structure when deposited on the surface of the substrate, reducing the porosity caused by thermal degradation [44]. Shah [45] and other researchers used high-density polyethylene powder particles as the spraying material, and deposited a coating on the surface of the semi-infinite high density polyethylene substrate by cold spraying technology. The impact speed of the sprayed material, temperature, diameter and particle composition of this series the influence of parameters on the impact dynamics of the particles, the study found that high-density polyethylene powder particles are easier to deposit on harder substrates. $\mathrm{Xu}$ [46] and other researchers used polyolefin powder particles as the spraying material, and prepared amphetamine alcohol coating on the surface of polyethylene and aluminum substrates by cold spraying technology, as shown in Figure 7 , the research results show that: the heating temperature is lower than the polymer temperature in order to ensure that the polymer will not melt, the powder particles are closely combined through the interaction of plastic deformation. Tillmann [47] and other researchers used cold spray technology to prepare a $450 \mu \mathrm{m}$ polyamide-12/ $\mathrm{Al}_{2} \mathrm{O}_{3}$ composite coating on the surface of steel substrates. Studies have shown that $\mathrm{Al}_{2} \mathrm{O}_{3}$ ceramic powders particle can accelerate the fluidity of polymer powders and simultaneously to shot peening. RAVIK [42]. Used super-hydrophobic polymers as the spraying material, and prepared a coating on the surface of the 316 stainless steel substrate by cold particle spraying single particle deposition to improve the surface performance of the substrate. The results showed that the surface of the substrate was coated with a layer of papillae the Micro-nano-structured hydrophobic Nanoceramic layer of the same structure also improves the deposition efficiency of the particles.

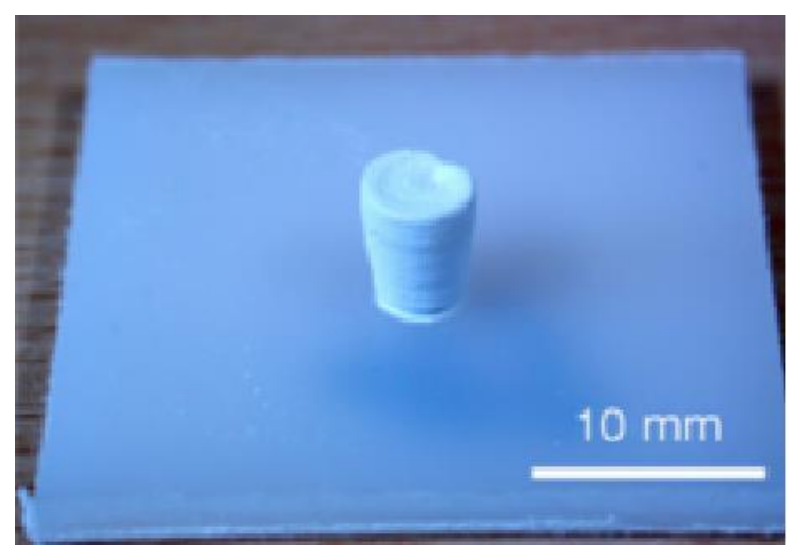

Figure 7. Amphetamine coating [46]

\subsection{Ceramic powder materials}

Generally, nano/sub-Micron ceramic particle powders are used as a spray material for cold spray technology. A few micron-sized powders are formed by agglomeration of nano-powders by sol-gel method [48], which is deposited on the surface of the substrate driven by a high subsonic acceleration medium. Compared with polymer powder and metal powder, the biggest feature of ceramic powder is that it has no plasticity at low temperature, so it is more difficult to deposit on the surface of the substrate. Ceramic powder particles have many advantages as a spray material for cold spray technology: low temperature, economy, and simple operation. Wang [49] and others researchers found that the deposition mechanism of ceramic powder particles is divided into two types, one is the bonding of ceramic powder particles to the substrate, the way is mechanical occlusion; the other is the deposition inside the ceramic powder coating, the way divided into grain refinement, plastic deformation and grain refinement-compaction mechanism. Liu [50] and others researchers found that using TiN ceramic powder particles as the spraying material, during the VCS (vacuum cold spray) spray deposition process, the TiN ceramic powder particles showed obvious cracks and plastic deformation, because the TiN ceramic powder particles were in the process of high-speed impact Induced strain occurs in the powder particles. The density of the individual particles is $\sim 5 \times$ $1017 / \mathrm{m}^{2}$. The density of the TiN ceramic powder particles will form an amorphous layer with a width of 3-4 nm. The reason for the misalignment is the high density of the individual powder particles. High stress 
and strain cause amorphization at the TiN interface, as shown in Figure 8. Sung [51]. Found that using cold spray technology to spray mixed powder particles of different diameters on the surface of the fluorine-doped tin oxide electrode, the results showed that the sprayed coating can generate a porous $\mathrm{TiO}_{2}$ layer, which was compared with the sample after annealing, Conversion efficiency increased by $62 \%$.

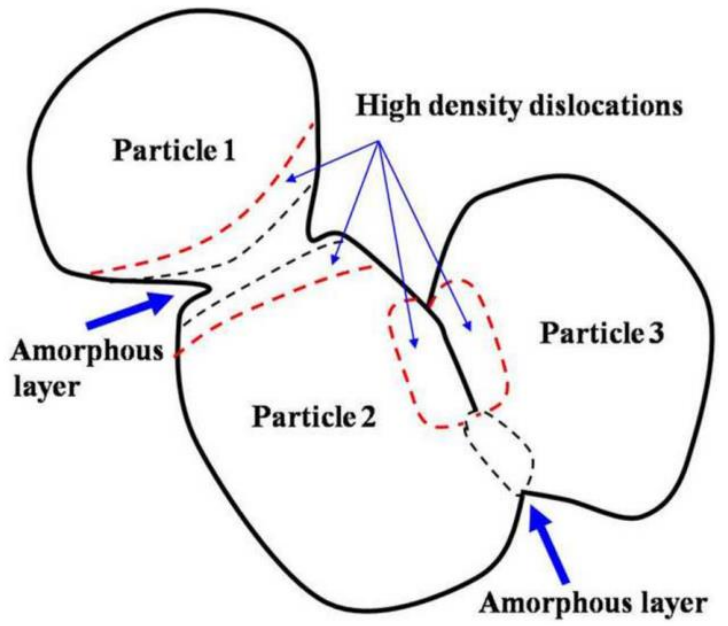

Figure 8. Schematic diagram of the amorphous layer at the TiN interface [50]

\section{Conclusion}

This article reviews the application of cold spray technology in spray materials and summarizes the literature on cold spray research. It mainly summarizes the existing conventional metals, rare metals and nonmetallic materials. At present, $\mathrm{Cu}, \mathrm{Ti}, \mathrm{Al}$ and Ni-based metal materials are commonly used in cold spraying technology, but the main research is focused on $\mathrm{Al}, \mathrm{Cu}$ and Ti-based metal materials, and the research of $\mathrm{Mg}$ based metals is still in the initial exploration period, although Titanium's there are many studies, but due to its own high hardness, the compactness and mechanical properties of the deposited layer restrict its own use in the industrial field. The application of rare metal tungsten series, tantalum series and niobium series metal materials in the field of cold spraying technology is still in its infancy. Non-metallic materials are mainly polymer materials and ceramic powder materials. As a new spraying material, this material has the characteristics of surface modification and strengthening technology. It also has low oxygen content, low thermal stress, high density, and combination. The strength is good, and the advantages of itself and the physical structure of the substrate will not be changed during the deposition process.
At present, the reliability of rare metal coatings is still a problem worthy of study, how to improve the reliability of rare metal coatings and thus improve the mechanical properties of the coatings. The mechanical properties of the joint between the coating of the nonmetallic material and the substrate are poor and the bonding mechanism is unclear, especially in the case of low bonding force. The use of ceramic powder as a cold spray material for deposition on metal substrates, especially for the preparation of high-temperature coatings, has very little application research, which will be the focus of future research.

\section{References (GOST 7.1:2006)}

1. Champagne, $V$. The unique abilities of cold spray deposition [Text] / V. Champagne, D. Helfritch // International Materials Reviews. - 2016. - Vol. 61, Iss. 7. - P. 437-455. DOI: 10.1080/09506608.2016.1194948.

2. Bonding Mechanism in Cold Gas Spraying [Text] / H. Assadi, F. Gärtner, T. Stoltenhoff, H. Kreye // Acta Materialia. - 2003. - Vol. 51, Iss. 15. - P. 4379-4394. DOI: 10.1016/s1359-6454(03)00274-x.

3. Cold Spraying: From Process Fundamentals Towards Advanced Applications [Text] / S. Grigoriev, A. Okunkova, A. Sova, P. Bertrand, I. Smurov // Surface \& Coatings Technology. - 2015. - Vol. 268. - P. 77-84. DOI: 10.1016/j.surfcoat.2014.09.060

4. Stoltenhoff, T. An analysis of the cold spray process and its coatings [Text] / T. Stoltenhoff, H. Kreye, H. J. Richter // Journal of Thermal Spray Technol. - 2002. - Vol. 11. - P. 542-550. DOI: 10.1361/10599630277034 8682.

5. Research on cold spraying aluminum coating and its wear resistance [Text] / Jia Li, Cui Yun, Liu Guang, Zheng Ziyun // Ordnance Material Science and Engineering. - 2017. - Vol. 40, Iss. 3. - P. 78-80.

6. Xuefei, Li. Application and prospect of cold spraying in welding engineering [Text] / Li Xuefei, Li Jinglong, Li Wenya // Welding \& Joining. - 2008. - Iss. 9. - P. 13-16.

7. Research Progress of Oxidizing Sensitive Nonferrous Metals Produced by Cold Spray [Text] / Yang Lijing, Zhang Pingxiang, Wang Shaopeng, Li Zhengxian // Thermal Spray Technology. - 2018. - Vol. 10, Iss. 4. P. 23-32.

8. Zhenghan, Chen. Application study of cold spray technology in maintenance of copper propeller [Text] / Chen Zhenghan, Sun Xiaofeng, Shi Yupeng // Theoretical Exploration. - 2016. - Vol. 8, Iss. 3. - P. 20-24.

9. Deposition behavior and corrosion resistance of cold sprayed Cu-based composite coatings [Text] / Zhang Mengqing, Qiao Yulin, Zhang Zhong, Zhang Wei, Yu Helong // Modern Salt and Chemical Industry. - 2019. - Vol. 46, Iss. 5. - P. 35-36. 
10. Tribological Behavior of a Cold-Sprayed $\mathrm{Cu}-$ MoS2 Composite Coating During Dry Sliding Wear [Text] / Y. Zhan, J. M. Shockley, Phuong Vo, Richard R. Chromik // Tribology Letters. - 2016. - Iss. 1. - P. 9.

11. Lingling, Xu. Preparation and Research of Cold Spray Thermal Conductive Copper Coating [Text] / Xu Lingling, Zhou Xianglin, Sun Chengchuan // Thermal Spray Technology. - 2017. - Vol. 9, Iss. 04. - P. 7-12.

12. Improvement of microstructure and property of cold-sprayed $\mathrm{Cu}-4$ at.\%Cr-2 at.\%Nb alloy by heat treatment [Text] / W.-Y. Li, X. P. Guo, C. Verdy, L. Dembinski, H. L. Liao, C. Coddet // Scripta Materialia. 2006. - Vol. 55, Iss. 4. - P. 327-330. DOI: 10.1016/j.scriptamat.2006.04.041.

13. Using friction stir processing to augment corrosion resistance of cold sprayed AA2024/Al2O3 composite coatings [Text] / Kang Yang, Wenya Li, Yaxin Xu, Xiawei Yang // Journal of Alloy Compounds. - 2019. - Vol. 774. - P. 1223-1232. DOI. 10.1016/j.jallcom.2018.09.386.

14. Solid-state additive manufacturing and repairing by cold spraying: A review [Text] / Wenya Li, et al. // Journal of Materials Science \& Technology. 2018. - Vol. 34, No. 3. - P. 440-457. DOI: 10.1016/j.jmst.2017.09.015.

15. Huang, R. Development of ultra-strong adhesive strength coatings using cold spray [Text] / R. Huang, W. Ma, H. Fukanuma // Surface and Coatings Technology.2013. - Vol. 258. - P. 832-841. DOI: 10.1016/j.surfcoat.2014.07.074.

16. Significant influences of metal reactivity and oxide films at particle surfaces on coating microstructure in cold spraying [Text] / W.-Y. Li, C. Zhang, et al. // Applied Surface Science. - 2007. - Vol. 253, No. 7. - P. 3557-3562. DOI: 10.1016/j.apsusc.2006.07.063.

17. Li, Wenya. The effect of vacuum heat treatment on the microstructure and tensile properties of cold sprayed porous Ti [Text] / Wenya Li, Yumin Yu, Hanlin Liao // Chinese Journal of Nonferrous Metals. - 2010. Vol. 20, No. 10. - P. 902-905.

18. Wang, Qi. The galvanic corrosion behavior of cold sprayed Ti coating and 1Cr13 stainless steel [Text] / Qi Wang, Hongren Wang, Min Du // Corrosion and Protection. - 2006. - Vol. 27, No. 11. - P. 544-547.

19. Microstructure and Mechanical Property of Ti and Ti6Al4V Prepared by an In-situ Shot Peening Assisted Cold Spraying [Text] / X.-T. Luo, Y.-K. Wei et al. // Materials and Design. - 2015. - Vol. 85. - P. 527-533. DOI: 10.1016/j.matdes.2015.07.015.

20. Zhang, J. Effect of standoff distance on properties of Al coating during cold spraying [Text] / Jianfeng Zhang, Zhijin Chen, Jianhua Yao // Heat treatment of metals. - 2014. - Vol. 39, No. 06. - P. 88-90. DOI: 10.13251/j.issn.0254-6051.2014.06.023.

21. Champagne, V. K. The repair of magnesium rotor-craft components by cold spray [Text] / V. K.
Champagne // Journal of Failure Analysis \& Prevention. -2008. - Vol. 8. - P. 164-175. DOI: 10.1007/s11668-0089116-y.

22. Novoselova, T. Formation of TiAl inter metallics by heat treatment of cold-sprayed precursor deposits [Text] / T Novoselova, S. Celotto, R Morgan // Journal of Alloys \& Compounds. - 2007. - Vol. 436, Iss. 1-2. - P. 69 77. DOI: 10.1016/j.jallcom.2006.06.101.

23. Modeling of Erosion Response of Cold-Sprayed In718-Ni Composite Coating Using Full Factorial Design [Text] / E Verna, R Biagi, M. Kazasidis, M. Galetto, E. Bemporad, R Lupoi // Coatings. - 2020. Vol. 10, Iss. 4. Article Id: 335. DOI: 10.3390/coatings10040335.

24. Microstructure and cavitation erosion performance of nickel-Inconel 718 composite coatings produced with cold spray [Text] / Marios Kazasidis, Shuo Yin, Jonathan Cassidy, Tatjana Volkov-Husović, Milica Vlahović, Sanja Martinović, Elena Kyriakopoulou, Rocco Lupoi // Surface and Coatings Technology. - 2020. - Vol. 382. - Article Id: 125195. DOI: 10.1016/j.surfcoat.2019.125195.

25. Study of the Method of Obtaining Functional Interest-Metallic Coatings Based on Ni-Ti Reinforced with WC Nanoparticles [Text] / A. M. Makarov, Dmitry A. Gerashchenkov, Sergey E. Aleksandrov et al. // Key Engineering Materials. - 2019. - Vol. 822. - P. 760-767. DOI: $10.4028 / w w w . s c i e n t i f i c . n e t / k e m .822 .760$.

26. Scendo, Mieczyslaw. Influence of Nickel Powders on Corrosion Resistance of Cold Sprayed Coatings on Al7075 Substrate [Text] / Mieczyslaw Scendo, Wojciech Zorawski, Anna Goral // Metals. 2019. - Vol. 9, Iss. 8. - Article Id: 890. DOI: 10.3390/met9080890.

27. Corrosion resistant nickel coating with strong adhesion on AZ31B magnesium alloy prepared by an insitu shot-peening-assisted cold spray [Text] / Ying-Kang Wei, Yu-Juan Li, Yue Zhang, Xiao-Tao Luo, Chang-Jiu Li // Corrosion Science. - 2018. - Vol. 138. - P. 105-115. DOI: 10.1016/j.corsci.2018.04.018.

28. Deposition Behavior in Cold Sprayed CopperTungsten Metal Matrix Composites [Electronic resource] I Aaron Hall, Pylin Sarobol, David Urrea, Stephen Miller. - Sandia National Lab. (SNL-NM), Albuquerque, NM (United States), 2015. - 4 p. - Access mode: https://www. osti.gov/servlets/purl/1244889. - 12.10.2020.

29. Kang, Hyun-Ki. Tungsten/copper composite deposits produced by a cold spray [Text] / Hyun-Ki Kang, Suk-Bong Kang // Scripta Materialia. - 2003. - Vol. 49, Iss. 12. - P. 1169-1174. DOI: 10.1016/j.scriptamat. 2003. 08.023 .

30. Jones, M. Solid-state manufacturing of tungsten deposits onto molydenum substrates with supersonic laser deposition [Text] / M. Jones, A. Cockburn, R. Lupoi // Materials Letters. - 2014. - Vol. 134. - P. 295-297. DOI: 10.1016/j.matlet.2014.07.091. 
31. Research Progress on Strengthening and Toughening of Refractory Tantalum Based Alloys for Ultra-high-temperature Applications [Text] / Hu Kongsheng, Xiao Xuan, Dong Xianjuan et al. // Hot Working Technology. - 2014. - Iss. 24. - P. 19-22.

32. Yong, Tang. Research progress of high temperature oxidation resistance of tantalum-based alloy [Text] / Tang Yong, Du Jihong, Zhengxian Li // Science and Technology Information. - 2016. - Iss. 9. - P. 150152.

33. Koivuluoto, H. Corrosion Properties of ColdSprayed Tantalum Coatings [Text] / H. Koivuluoto, J. Näkki, P. Vuoristo // Journal of Thermal Spray Technology. - 2009. - Vol. 18. - P. 75-82. DOI. 10.1007/s11666-008-9281-2.

34. Corrosion resistance of cold-sprayed $\mathrm{Ta}$ coatings in very aggressive conditions [Text] / H. Koivuluoto, G. Bolelli, L. Lusvarghi, F. Casadei, P. Vuoristo // Surface and Coatings Technology. - 2010. - Vol. 205, Iss. 4. - P. 1103-1107. DOI: 10.1016/j.surfcoat.2010.02.052.

35. Depth-sensing indentation for assessing the mechanical properties of cold-sprayed Ta [Text] / G. Bolelli, B. Bonferroni, H. Koivuluoto, L. Lusvarghi, P. Vuoristo // Surface and Coatings Technology. - 2010. - Vol. 205, Iss. 7. - P. 2209-2217. DOI: 10.1016/j.surfcoat.2010.08.146.

36. Effect of Heat Treatment on Mechanical Properties and Corrosion Performance of Cold-Sprayed Tantalum Coatings [Text] / S. Kumar, V. Vidyasagar, A. Jyothirmayi, S. V. Joshi // Journal of Thermal Spray Technology. - 2016. - Vol. 25. - P. 745-756. DOI: 10.1007/s11666-016-0388-6.

37. Research progress in high temperature oxidation resistance of $\mathrm{Nb}$ and $\mathrm{Nb}$ based alloys [Text] / L. Yin, D. Q. Yi, L. R. Xiao, L. Yang // Materials Protection. - 2003. - Vol. 36, Iss. 8. - P. 4-8.

38. Influence of annealing on mechanical and electrochemical properties of cold sprayed niobium coatings [Text] / S. Kumar, A. Jyothirmayi, N. Wasekar, S. V. Joshi // Surface and Coatings Technology. - 2016. - Vol. 296. - P. 124-135. DOI: 10.1016/j.surfcoat. 2016. 04.027.

39. Correlation of splat state with deposition characteristics of cold sprayed niobium coatings [Text] / S. Kumar, M. Ramakrishna, N. M. Chavan, S. V. Joshi // Acta Materialia. - 2017. - Vol. 130. - P. 177-195. DOI: 10.1016/j.actamat.2017.03.023.

40. Lima, C. R.-C. Study of wear and corrosion performance of thermal sprayed engineering polymers [Text] / C. R.-C Lima, N. F. C. de Souza, F. Camargo // Surface and Coatings Technology. - 2013. - Vol. 220. P. 140-143. DOI: 10.1016/j.surfcoat.2012.05.051.

41. Properties of thermally sprayed fluoropolymer PVDF, ECTFE, PFA and FEP coatings [Text] / E. Leivo, T. Wilenius, T. Kinos et al. // Progress in Organic
Coatings. - 2004. - Vol. 49, Iss. 1. - P. 69-73. DOI: 10.1016/j.porgcoat.2003.08.011.

42. Influence of nanoceramic interlayer on polymer consolidation during cold spray coating formation [Text] / K. Ravi, T. Deplancke, O. Lame et al. // Journal of Materials Processing Technology. - 2019. - Vol. 273. Article Id: 116254. DOI: 10.1016/j.jmatprotec.2019. 116254

43. Understanding deposition mechanism in cold sprayed ultrahigh molecular weight polyethylene coatings on metals by isolated particle deposition method [Text] / K. Ravi, T. Deplancke, K. Ogawa et al. // Additive Manufacturing. - 2018. - Vol. 21. - P. 191-200. DOI: 10.1016/j.addma.2018.02.022.

44. Khalkhali, Z. Characterization of the cold spray deposition of a wide variety of polymeric powders [Text] / Z. Khalkhali, J.-P. Rothstein // Surface and Coatings Technology. - 2020. - Vol. 383. - Article Id: 125251. DOI 10.1016/j.surfcoat.2019.125251.

45. Shah, S. Numerical Simulations of the HighVelocity Impact of a Single Polymer Particle During Cold-Spray Deposition [Text] / S. Shah, J. Lee, J. P. Rothstein // Journal of Thermal Spray Technology. 2017. - Vol. 26. - P. 970-984. DOI: 10.1007/s11666-0170557-2.

46. Xu, Y. Cold spray deposition of thermoplastic powder [Text] / Y. Xu, I. M. Hutchings // Surface and Coatings Technology. - 2006. - Vol. 201, Iss. 6. - P. 3044-3050. DOI: 10.1016/j.surfcoat.2006.06.016.

47. Tillmann, $W$. Investigation of low-pressure coldgas dynamic spraying of polyamide-12 (PA12) on steel surfaces [Text] / W. Tillmann,. J. F. Zajaczkowski // IOP Conference Series: Materials Science and Engineering. - 2019. - Vol. 480. - Article Id: 012009. DOI: 10.1088/1757-899X/480/1/012009.

48. Preliminary studies of $\mathrm{TiO} 2$ nanopowder deposition onto metallic substrate by low pressure cold spraying [Text] / M. Winnicki, A. Baszczuk, M. Jasiorski // Surface and Coatings Technology. - 2019. - Vol. 371. - P. 194-202. DOI: 10.1016/j.surfcoat.2018.09.057.

49. Characterization of the Microstructure of Al2O3 Coating Deposited by Vacuum Cold Spray [Text] / Lishuang Wang, Heng-fu Zhou, Cheng-xin Li, Yu-yue Wang, Guan-jun Yang, Xiao-tao Luo, Chang-jiu Li // Thermal Spray Technology. - 2017. - Vol. 9, Iss. 03. - P. 36-45.

50. Impact-induced bonding and boundary amorphization of TiN ceramic particles during room temperature vacuum cold spray deposition [Text] / Y. Liu, Y. Wang, X. Suo, Y. Gong, C. Li, H. Li // Ceramics International. - 2016. - Vol. 42, Iss. 1, Part B. - P. 1640 1647. DOI: 10.1016/j.ceramint.2015.09.116.

51. Cho, S. H. Multi-layer TiO2 films prepared by aerosol deposition method for dye-sensitized solar cells [Text] / S. H. Cho, Y. J. Yoon // Thin Solid Films. - 2013. - Vol. 547. - P. 91-94. DOI: 10.1016/j.tsf.2013.04.107. 


\section{References (BSI)}

1. Champagne, V., Helfritch, D. The unique abilities of cold spray deposition. International Materials Reviews, 2016, vol. 61, iss. 7, pp. 437-455. DOI: 10.1080/09506608.2016.1194948.

2. Assadi, H., Gärtner, F, Stoltenhoff, T., Kreye, H. Bonding Mechanism in Cold Gas Spraying. Acta Materialia, 2003, vol. 51, no. 15, pp. 4379-4394. DOI: 10.1016/s1359-6454(03)00274-x.

3. Grigoriev, S., Okunkova, A., Sova, A., Bertrand, P., Smurov, I. Cold Spraying: From Process Fundamentals Towards Advanced Applications. Surface \& Coatings Technology, 2015, vol. 268, pp. 77-84. DOI: 10.1016/j.surfcoat.2014.09.060.

4. Stoltenhoff, T., Kreye, H., Richter, J. H. An analysis of the cold spray process and its coatings. Journal of Thermal Spray Technol., 2002, vol. 11, pp. 542-550. DOI: 10.1361/105996302770348682.

5. Li, Jia., Yun, Cui., Guang, Liu., Ziyun, Zheng. Research on cold spraying aluminum coating and its wear resistance. Ordnance Material Science and Engineering, 2017, vol. 40, iss. 3, pp. 78-80.

6. Xuefei, Li., Jinglong, Li., Wenya, Li. Application and prospect of cold spraying in welding engineering. Welding \& Joining, 2008, iss. 9, pp. 13-16.

7. Lijing, Yang., Pingxiang, Zhang., Shaopeng, Wang., Zhengxian, Li. Research Progress of Oxidizing Sensitive Non-ferrous Metals Produced by Cold Spray. Thermal Spray Technology, 2018, vol. 10, iss. 4, pp. 2332.

8. Zhenghan, Chen., Xiaofeng, Sun., Yupeng, Shi. Application study of cold spray technology in maintenance of copper propeller. Theoretical Exploration, 2016, vol. 8, iss. 3, pp. 20-24.

9. Mengqing, Zhang., Yulin, Qiao., Zhong, Zhang., Wei, Zhang., Helong, Yu. Deposition behavior and corrosion resistance of cold sprayed $\mathrm{Cu}$-based composite coatings. Modern Salt and Chemical Industry, 2019, vol. 46, iss. 5, pp. 35-36.

10. Zhang, Y., Shockley, J. M., Vo, P., Chromi, Richard R. Tribological Behavior of a Cold-Sprayed $\mathrm{Cu}-$ MoS2 Composite Coating During Dry Sliding Wear. Tribology Letters, 2016, iss. 1, pp. 9.

11. Lingling, Xu., Xianglin, Zhou., Chengchuan, Sun. Preparation and Research of Cold Spray Thermal Conductive Copper Coating. Thermal Spray Technology, 2017, vol. 9, iss. 4, pp. 7-12.

12. Li, W.-Y., Guo, X. P., Verdy, C. at al. Improvement of Microstructure and Property of Coldsprayed Cu-4 at.\%Cr-2 at.\%Nb Alloy by Heat Treatment. Scripta Materialia, 2006, vol. 55, iss. 4, pp. 327-330. DOI: 10.1016/j.scriptamat.2006.04.041.

13. Yang, K. et al. Using friction stir processing to augment corrosion resistance of cold sprayed
AA2024/A12O3 composite coatings. Journal of alloy compounds. 2019, vol. 774, pp. 1223-1232. DOI: 10.1016/j.jallcom.2018.09.386.

14. Li, W.-Y., et al. Solid-state additive manufacturing and repairing by cold spraying: A review. Journal of Materials Science \& Technology, 2018, vol. 34, no. 3, pp. 440-457. DOI: 10.1016/j.jmst.2017.09.015.

15. Huang, R., Ma, W., Fukanuma, H. Development of ultra-strong adhesive strength coatings using cold spray. Surface and Coatings Technology, 2013, vol. 258, pp. 832-841. DOI: 10.1016/j.surfcoat.2014.07.074.

$16 \mathrm{Li}$, W.-Y. et al. Significant influences of metal reactivity and oxide films at particle surfaces on coating microstructure in cold spraying. Applied Surface Science, 2007, vol. 253, no. 7, pp. 3557-3562. DOI: 10.1016/j.apsusc.2006.07.063.

17. Li, Wenya., Yu, Yumin., Liao, Hanlin. The effect of vacuum heat treatment on the microstructure and tensile properties of cold sprayed porous Ti. Chinese Journal of Nonferrous Metals, 2010, vol. 20, no. 10, pp. 902-905.

18. Wang, Qi., Wang, Hongren., Du, Min. The galvanic corrosion behavior of cold sprayed Ti coating and $1 \mathrm{Cr} 13$ stainless steel. Corrosion and Protection, 2006, vol. 27, no. 11, pp. 544-547.

19. Luo, X.-T., Wei, Y.-K. et al. Microstructure and Mechanical Property of Ti and Ti6Al4V Prepared by an In-situ Shot Peening Assisted Cold Spraying. Materials and Design, 2015, vol. 85, pp. 527-533. DOI: 10.1016/j.matdes.2015.07.015.

20. Zhang, J., Chen, Z., Yao, J. Effect of standoff distance on properties of Al coating during cold spraying. Heat treatment of metals, 2014, vol. 39, no. 06, pp. 8890. DOI: 10.13251/j.issn.0254-6051.2014.06.023.

21. Champagne, V. K. The repair of magnesium rotor craft components by cold spray. Journal of Failure Analysis \& Prevention, 2008, vol. 8, pp. 164-175. DOI: 10.1007/s11668-008-9116-y.

22. Novoselova, T., Celotto, S., Morgan, R. Formation of TiAl inter metallics by heat treatment of cold-sprayed precursor deposits. Journal of Alloys \& Compounds, 2007, vol. 436, iss. 1-2, pp. 69-77. DOI: 10.1016/j.jallcom.2006.06.101.

23. Verna, E., Biagi, R., Kazasidis, M. et al. Modeling of Erosion Response of Cold-Sprayed In718$\mathrm{Ni}$ Composite Coating Using Full Factorial Design. Coatings, 2020, vol. 10, iss. 4, article id: 335. DOI: 10.3390/coatings 10040335 .

24. Kazasidis, Marios., Yin, Shuo., Cassidy, Jonathan., Volkov-Husović, Tatjana., Vlahović, Milica., Martinović, Sanja., Kyriakopoulou, Elena., Rocco, Lupoi., Microstructure and cavitation erosion performance of nickel-Inconel 718 composite coatings produced with cold spray. Surface and Coatings Technology, 2020, vol. 382, article id: 125195. DOI: 10.1016/j.surfcoat.2019.125195. 
25. Makarov, A. M., Gerashchenkov, Dmitry A., Aleksandrov, Sergey E. et al. Study of the Method of Obtaining Functional Interest-Metallic Coatings Based on Ni-Ti Reinforced with WC Nanoparticles. Key Engineering Materials, 2019, vol. 822, pp. 760-767. DOI: 10.4028/www.scientific.net/kem.822.760.

26. Scendo, Mieczyslaw., Zorawski, Wojciech., Goral, Anna. Influence of Nickel Powders on Corrosion Resistance of Cold Sprayed Coatings on A17075 Substrate. Metals, 2019, vol. 9, iss. 8, article id: 890 . DOI: 10.3390/met9080890.

27. Wei, Ying-Kang., Li, Yu-Juan., Zhang, Yue., Luo, Xiao-Tao., Li, Chang-Jiu. Corrosion resistant nickel coating with strong adhesion on AZ31B magnesium alloy prepared by an in-situ shot-peening-assisted cold spray. Corrosion Science, 2018, vol. 138, pp. 105-155. DOI: 10.1016/j.corsci.2018.04.018.

28. Hall, Aaron., Sarobol, Pylin., Urrea, David., Miller, Stephen. Deposition Behavior in Cold Sprayed Copper-Tungsten Metal Matrix Composites. Sandia National Lab.(SNL-NM), Albuquerque, NM (United States), 2015. 4 p. Available at: https://www.osti.gov/ servlets/purl/1244889. - (accessed 15.04.2020).

29. Kang, Hyun-Ki., Kang, Suk-Bong. Tungsten/copper composite deposits produced by a cold spray. Scripta Materialia, 2003, vol. 49, iss. 12, pp. 11691174. DOI: 10.1016/j.scriptamat.2003.08.023.

30. Jones, M., Cockburn, A., Lupoi, R. Solid-state manufacturing of tungsten deposits onto molydenum substrates with supersonic laser deposition. Materials Letters, 2014, vol. 134, pp. 295-297. DOI: 10.1016/j.matlet.2014.07.091.

31. Hu, Kongsheng., Xuan, Xiao., Dong, Xianjuan., et al. Research Progress on Strengthening and Toughening of Refractory Tantalum Based Alloys for Ultra-high-temperature Applications. Hot Working Technology, 2014, iss. 24, pp. 19-22.

32. Yong, Tang., Jihong, Du., Li, Zhengxian. Research progress of high temperature oxidation resistance of tantalum-based alloy. Science and Technology Information, 2016, iss. 9, pp. 150-152.

33. Koivuluoto, H., Näkki, J., Vuoristo, P. Corrosion Properties of Cold-Sprayed Tantalum Coatings. Journal of Thermal Spray Technology, 2009, vol. 18, pp. 75-82. DOI: $10.1007 / \mathrm{s} 11666-008-9281-2$.

34. Koivuluoto, H., Bolelli, G., Lusvarghi, L., Casadei, F., Vuoristo, P. Corrosion resistance of coldsprayed Ta coatings in very aggressive conditions. Surface and Coatings Technology, 2010, vol. 205, iss. 4, pp. 1103-1107. DOI: 10.1016/j.surfcoat.2010.02.052.

35. Bolelli, G., Bonferroni, B., Koivuluoto, H., Lusvarghi, L., Vuoristo, P. Depth-sensing indentation for assessing the mechanical properties of cold-sprayed Ta. Surface and Coatings Technology, 2010, vol. 205, iss. 7, pp. 2209-2217. DOI: 10.1016/j.surfcoat.2010.08.146.

36. Kumar, S., Vidyasagar, V., Jyothirmayi, A.,
Joshi, V, S. Effect of Heat Treatment on Mechanical Properties and Corrosion Performance of Cold-Sprayed Tantalum Coatings. Journal of Thermal Spray Technology, 2016, vol. 25, pp. 745-756. DOI: 10.1007/s11666-016-0388-6.

37. Yin, L., Yi, D., Xiao, L., Yang, L. Research progress of high temperature oxidation resistance of niobium and niobium alloys. Materials Protection, 2003, vol. 36, iss. 8, pp. 4-8.

38. Kumar, S., Jyothirmayi, A., Wasekar, N., Joshi, V.S. Influence of annealing on mechanical and electrochemical properties of cold sprayed niobium coatings. Surface and Coatings Technology, 2016, vol. 296, pp. 124-135. DOI: 10.1016/j.surfcoat.2016.04.027.

39. Kumar, S., Ramakrishna, M., Chavan, N. M., Joshi, V. S. Correlation of splat state with deposition characteristics of cold sprayed niobium coatings. Acta Materialia, 2017, vol. 130, pp. 177-195. DOI: 10.1016/j.actamat.2017.03.023.

40. Lima, C. R.-C. et al. Study of wear and corrosion performance of thermal sprayed engineering polymers. Surface and Coatings Technology, 2013, vol. 220, pp. 140-143. DOI: 10.1016/j.surfcoat.2012.05.051.

41. Leivo, E., Wilenius, T., Kinos, T. et al. Properties of thermally sprayed fluoropolymer PVDF, ECTFE, PFA and FEP coatings. Progress in Organic Coatings, 2004, vol. 49, iss. 1, pp. 69-73. DOI: 10.1016/j.porgcoat.2003.08.011.

42. Ravi, K., Deplancke, T., Lame, O. et al. Influence of nanoceramic interlayer on polymer consolidation during cold spray coating formation. Journal of Materials Processing Technology, 2019, vol. 273, article id: 116254 DOI: 10.1016/j.jmatprotec.2019.116254.

43. Ravi, K., Deplancke, T., Ogawa, K. et al. Understanding deposition mechanism in cold sprayed ultrahigh molecular weight polyethylene coatings on metals by isolated particle deposition method. Additive Manufacturing, 2018, vol. 21, pp. 191-200. DOI: 10.1016/j.addma.2018.02.022.

44. Khalkhali, Z., Rothstein, J.-P. Characterization of the cold spray deposition of a wide variety of polymeric powders. Surface and Coatings Technology, 2020, vol. 383, article id: 125251. DOI: 10.1016/j.surfcoat.2019.125251.

45. Shah, S., Lee, J., Rothstein, J. P. Numerical Simulations of the High-Velocity Impact of a Single Polymer Particle During Cold-Spray Deposition. Journal of Thermal Spray Technology, 2017, vol. 26, pp. 970-984. DOI: 10.1007/s11666-017-0557-2.

46. Xu, Y., Hutchings, I. M. Cold spray deposition of thermoplastic powder. Surface and Coatings Technology, 2006, vol. 201, iss. 6, pp. 3044-3050. DOI: 10.1016/j.surfcoat.2006.06.016.

47. Tillmann, W., Zajaczkowski, J. F. Investigation of low-pressure cold-gas dynamic spraying of 
polyamide-12 (PA12) on steel surfaces. IOP Conference Series: Materials Science and Engineering, 2019, vol. 480, article id: 012009. DOI: 10.1088/1757899X/480/1/012009.

48. Winnicki, M., Baszczuk, A., Jasiorski, M. Preliminary studies of TiO2nanopowder deposition onto metallic substrate by low pressure cold spraying. Surface and Coatings Technology, 2019, vol. 371, pp. 194-202. DOI: 10.1016/j.surfcoat.2018.09.057.

49. Wang, Li-shuang., Zhou, Heng-fu., Li, Chengxin., Wang, Yu-yue., et al. Characterization of the Microstructure of Al2O3 Coating Deposited by Vacuum
Cold Spray. Thermal Spray Technology, 2017, vol. 9, iss. 03, pp. 36-45.

50. Liu, Y., Wang, Y., Suo, X., et al. Impact-induced bonding and boundary amorphization of TiN ceramic particles during room temperature vacuum cold spray deposition. Ceramics International, 2016, vol. 42, iss. 1, pp. 1640-1647. DOI: 10.1016/j.ceramint.2015.09.116.

51. Cho, S. H., Yoon, Y. J. Multi-layer TiO2 films prepared by aerosol deposition method for dye-sensitized solar cells. Thin Solid Films, 2013, vol. 547, pp. 91-94. DOI: $10.1016 /$ j.tsf.2013.04.107.

Поступила в редакцию 15.01.2020, рассмотрена на редколлегии 16.02.2020

\title{
АНАЛІЗ ПОРОШКОВИХ МАТЕРІАЛІВ ДЛЯ ХОЛОДНОГО ГАЗОДИНАМІЧНОГО НАПИЛЮВАННЯ ТА ОБЛАСТЕЙ ЇХ ЗАСТОСУВАННЯ
}

\author{
Кунь Тань, С. С. Маркович, Веньцзе Ху, О. В. Шорінов, Юронг Ван
}

Технологія холодного газодинамічного напилювання - перспективна та багатообіцяюча технологія формування покриттів. Дана технологія має багато переваг в порівнянні 3 іншими технологіями газотермічного напилювання, а саме: можливість отримання товстих покриттів, мінімальні значення пористості, відсутність окислювальних процесів матеріалів покриття й підкладки, задовільні фізико-механічні характеристики й високі значення коефіцієнта використання порошку. Холодним газодинамічним напилюванням можливо отримання корозійностійких, теплозахисних, зносостійких та інших функціональних покриттів. Розвиток і вивчення процесу напилювання дозволяє отримувати покриття з широкого діапазону металевих порошків, а також інших метало-керамічних порошкових сумішей. Технологія холодного газодинамічного напилення добре зарекомендувала себе в процесах відновлення пошкоджених поверхонь, а також при необхідності забезпечення спеціальних експлуатаційних властивостей поверхонь деталей. У даній роботі розглядається застосування технології холодного напилення з точки зору порошкових матеріалів: металів, як пластичних (мідь, алюміній, цинк та ін.), так й важкооброблюваних (наприклад, титан), а також метало-керамічних композиційних порошкових сумішей на основі карбідів і оксидів. 3 проведеного аналізу літературних джерел можна зробити наступні висновки. У разі пластичних металів, процес формування покриттів і їх застосування в промисловості в достатній мірі вивчені. Позитивні результати по нанесенню покриттів 3 титанових сплавів були отримані при холодному газодинамічному напилюванні 3 використанням дорогих систем високого тиску та гелію в якості робочого газу. Що стосується тугоплавких металів (наприклад, вольфрам, тантал, ніобій), а також керамічних порошків (оксид алюмінію, оксид кремнію та ін.), то їх напилювання можливо лише за наявності металевої зв'язуючої компоненти. В даний час особливий практичний інтерес має застосування технології холодного напилювання металевих покриттів на композитні матеріали, пластики та інші неметалеві поверхні. Технологія холодного газодинамічного напилювання не обмежується представленими в статті результатами аналізу порошкових матеріалів і областями застосування, а дає загальне розуміння широких можливостей даної технології і конкуренції традиційним методам газотермічного напилювання.

Ключові слова: холодне напилення; авіація; металеві матеріали; полімерні матеріали; керамічні порошкові матеріали.

\section{АНАЛИЗ ПОРОШКОВЫХ МАТЕРИАЛОВ ДЛЯ ХОЛОДНОГО ГАЗОДИНАМИЧЕСКОГО НАПЫЛЕНИЯ И ОБЛАСТЕЙ ИХ ПРИМЕНЕНИЯ}

\section{Кунь Тань, С. Е. Маркович, Веньцзе ХУ, А. В. Шоринов, Юронг Ван}

Технология холодного газодинамического напыления - перспективная и многообещающая технология формирования покрытий. Данная технология обладает множеством достоинств в сравнении с другими технологиями газотермического напыления, а именно: возможность получения толстых покрытий, 
минимальные значения пористости, отсутствие окислительных процессов материалов покрытия и подложки, удовлетворительные физико-механические характеристики и высокие значения коэффициента использования порошка. Холодным газодинамическим напылением возможно получение коррозионностойких, теплозащитных, износостойких и других функциональных покрытий. Развитие и изучение процесса напыления позволяет получать покрытия из широкого диапазона металлических порошков, а также других металло-керамических порошковых смесей. Технология холодного газодинамического напыления хорошо зарекомендовала себя в процессах восстановления поврежденных поверхностей, а также при необходимости обеспечения специальных эксплуатационных свойств поверхностей деталей. В данной работе рассматривается применение технологии холодного напыления с точки зрения порошковых материалов: металлов, как пластичных (медь, алюминий, цинк и др.), так и труднообрабатываемых (например, титан), а также металло-керамических композиционных порошковых смесей на основе карбидов и оксидов. Из проведенного анализа литературных источников можно сделать следующие выводы. В случае пластичных металлов, процесс формирования покрытий и их применение в промышленности в достаточной степени изучены. Положительные результаты по нанесению покрытий из титановых сплавов были получены при холодном газодинамическом напылении с использованием дорогостоящих систем высокого давления и гелия в качестве рабочего газа. Что касается тугоплавких металлов (например, вольфрам, тантал, ниобий), а также керамических порошков (оксид алюминия, оксид кремния и др.), то их напыление возможно лишь с наличием металлической связующей компоненты. В настоящее время особый практический интерес имеет применение технологии холодного напыления металлических покрытий на композитные материалы, пластики и другие неметаллические поверхности. Технология холодного газодинамического напыления не ограничивается представленными в статье результатами анализа порошковых материалов и областями применения, а дает общее понимание широких возможностей данной технологии и конкуренции традиционным методам газотермического напыления.

Ключевые слова: холодное напыление; авиация; металлические материалы; полимерные материалы; керамические порошковые материалы.

Кунь Тань - аспірант факультету авіаційних двигунів, Національний аерокосмічний університет ім. М. Є. Жуковського «Харківський авіаційний інститут», Харків, Україна; Китайська Стипендіальна Рада, Китай.

Маркович Сергій Свгенович - канд. техн. наук, доцент, помічник проректора з інновацій, Національний аерокосмічний університет ім. М. С. Жуковського «Харківський авіаційний інститут», Харків, Україна.

Веньцзе Ху - аспірант факультету авіаційних двигунів, Національний аерокосмічний університет iм. М. Є. Жуковського «Харківський авіаційний інститут», Харків, Україна; Школа аеронавтики i космонавтики, Наньчанський технологічний інститут, Китай.

Шорінов Олександр Володимирович - канд. техн. наук, старш. викл. каф. технології виробництва авіаційних двигунів, Національний аерокосмічний університет ім. М. С. Жуковського «Харківський авіаційний інститут», Харків, Україна.

Юронг Ван - Комерційна авіабудівна корпорація Китаю.

Kun Tan - PhD student of Faculty of aircraft engines, National Aerospace University "Kharkiv Aviation Institute", Kharkiv, Ukraine; China Scholarship Council, e-mail: tankun09@126.com, ORCID: 0000-0003-4889-785X.

Sergii Markovych - PhD, Associate professor of Dept. of aircraft engine manufacturing technologies, Deputy rector for innovation, National Aerospace University "Kharkiv Aviation Institute”, Kharkiv, Ukraine, e-mail: s.markovych@khai.edu, https://scholar.google.com.hk/citations?hl=zh-CN\&user=1qCHkosAAAAJ

Wenjie Hu - PhD student of Faculty of aircraft engines, National Aerospace University "Kharkiv Aviation Institute", Kharkiv, Ukraine; School of Aeronautics and Astronautics, Nanchang Institute of Technology, China, e-mail: 837406613@qq.com, ORCID: 0000-0001-9540-1912.

Oleksandr Shorinov - PhD, Senior Lecturer of Dept. of aircraft engine manufacturing technologies, National Aerospace University "Kharkiv Aviation Institute”, Kharkiv, Ukraine,

e-mail: o.shorinov@khai.edu, ORCID: 0000-0002-5057-6679, https://scholar.google.com.hk/citations?hl=zh-CN\&user=xLOM1ccAAAAJ

Yurong Wang - Commercial Aircraft Corporation of China Ltd, China, e-mail: wangyurong993@126.com. 